\title{
Data for an Importance-Performance Analysis (IPA) of a Public Green Infrastructure and Urban Nature Space in Perth, Western Australia
}

\author{
Greg D. Simpson ${ }^{1, *(1)}$ and Jackie Parker ${ }^{2}$ \\ 1 College of Science, Health, Engineering, and Education-Environmental and Conservation Sciences, \\ Murdoch University, Perth 6150, WA, Australia \\ 2 School of Design and Built Environment, Curtin University, Perth 6102, WA, Australia; \\ 17966131@student.curtin.edu.au \\ * Correspondence: G.Simpson@murdoch.edu.au
}

Received: 23 November 2018; Accepted: 12 December 2018; Published: 17 December 2018

\begin{abstract}
This Data Descriptor shares the dataset generated by a visitor satisfaction survey of users of a mixed-use public green infrastructure (PGI) space in Perth, Western Australia, that incorporates remnant and reintroduced urban nature (UN). Conducted in the Austral summer of 2016-2017, the survey $(n=393)$ utilized the technique of Importance-Performance Analysis (IPA) to elucidate perceptions of PGI users regarding performance of the amenity and facilities at the study site. There is a growing body of research that reports the innate, inbuilt affinity of humans to natural systems and living things. As humankind has grown exponentially over the past 50 years, humanity, as a species, is living an increasingly urbanized lifestyle, resulting in spreading urban footprints and increased population densities that are causing humans to become increasingly disconnected from nature. These conflicting phenomena are driving research to understand the contribution that PGI and UN can make to enhancing the quality of life of urban residents. With diminishing opportunities to acquire or create new PGI spaces within ever-more-densely populated urban centers, understanding, efficiently managing, and continuously improving existing PGI spaces is crucial to access the benefits and services that PGI and UN provide. The IPA technique can provide the data necessary to inform an evidenced-based approach to managing and resourcing PGI and UN spaces.
\end{abstract}

Dataset: The dataset has been submitted for publication as a supplement to this Data Descriptor

Dataset License: CC-BY

Keywords: biophilic design; green infrastructure; Importance-Performance Analysis; IPA; public amenity; public open space; renaturing cities; urban nature; urban planning; visitor satisfaction

\section{Summary}

In addition to the rapid growth of humankind over the past 50 years, humanity, as a species, is becoming increasingly urbanized [1-3]. The Biophilic Hypothesis proposed by Wilson [4] states that humans have an innate, inbuilt affinity to natural systems and living things; however, the increase in the urban footprint and population density is causing human populations to become increasingly disconnected from nature $[3,5,6]$. These phenomena are driving research into the ways that public green infrastructure (PGI) and urban nature (UN) can enhance the quality of life of urban residents (e.g., [3,5,7-13]). With diminishing opportunities to acquire and/or create new PGI spaces within ever-more-densely populated urban centers, understanding, efficiently managing, and continuously 
improving existing PGI spaces is crucial to access the benefits and services that PGI and UN provide for humankind [10,12].

This Data Descriptor shares the dataset for an Importance-Performance Analysis (IPA) survey conducted at a PGI space in Perth, Western Australia. While underutilized in the management of PGI spaces [11,13], IPA techniques provide a relatively simple and straightforward method for quantitatively assessing the performance of PGI and UN spaces. The analysis and insights arising from this dataset are reported in the Research Article by Parker and Simpson [12] published in the Landscape Urbanism and Green Infrastructure special issue of the MDPI journal Land.

Informed by the review article of Parker and Simpson [11,13] and the IPA research of Newsome et al. [14], Soldić Frleta [15], and Taplin [16], a pen-and-paper-based self-report questionnaire was developed in order to survey visitors to the Lake Claremont PGI space. The questionnaire was designed to gather data regarding the demographic profile of PGI users, and their perceptions regarding the performance of 19 attributes of quality PGI spaces identified from the literature and 3 site-specific attributes (see Section 2). A convenience intercept survey was carried out at the Lake Claremont PGI space in the 2016-2017 Austral summer, coinciding with the peak summer holiday and recreation period $[3,17,18]$.

The demographic and IPA data collected during that survey are shared via the comma separated variable (.csv) file attached to this Data Descriptor as Supplementary Materials. Publication of this data has the potential to benefit others who are researching, planning, and managing urban PGI and UN with the goals of contributing to better PGI, enhancing the protection and renaturing of UN, and creating healthier and more liveable urban environments.

As reported above, the research associated with the dataset shared in this Data Descriptor has produced a systematic quantitative literature review article [11], the associated Data Descriptor [13], and contributed to the publication of an IPA-focused research article [12].

\section{Data Description}

The data extracted from the 393 questionnaires completed by PGI users were captured in Microsoft Excel and are provided as a .csv file with this Data Descriptor. The de-identified demographic data recorded for each participant is described in Tables 1-3.

Table 1. The metadata specification for gender data.

\begin{tabular}{|c|c|c|c|}
\hline \multicolumn{4}{|c|}{ Question 1: How Do You Describe Yourself? } \\
\hline Identifier & Descriptor & Data Type & Data Values \\
\hline D1 & Gender & Categorical & $\begin{array}{l}1=\text { Female } \\
2=\text { Male } \\
3=\text { Other } \\
4=\text { Prefer not to disclose } \\
5=\text { No Response }\end{array}$ \\
\hline
\end{tabular}

Table 2. The metadata specification for age data.

\begin{tabular}{|c|c|c|c|}
\hline \multicolumn{4}{|c|}{ Question 2: Which Age Group Do You Belong to? } \\
\hline Identifier & Descriptor & Data Type & Data Values \\
\hline D2 & Age & Categorical & $\begin{array}{l}1=18 \text { to } 24 \text { Years of Age } \\
2=25 \text { to } 34 \text { Years of Age } \\
3=35 \text { to } 44 \text { Years of Age } \\
4=45 \text { to } 54 \text { Years of Age } \\
5=55 \text { to } 64 \text { Years of Age } \\
6=65+\text { Years of Age } \\
7=\text { No Response }\end{array}$ \\
\hline
\end{tabular}


Table 3. The metadata specification for usual place of residence data.

Question 3: Where do you live? Please Tick the Box Most Relevant to You and STATE the Suburb/Town/City/Country of Residence

\begin{tabular}{|c|c|c|c|}
\hline Identifier & Descriptor & Data Type & Data Values \\
\hline D3 & Place of Residence & Categorical & $\begin{array}{l}1=\text { Surrounding Suburbs }(<5 \mathrm{~km}) \\
2=\text { Other Metropolitan Suburbs } \\
3=\text { Regional Western Australia } \\
4=\text { Other Australian States } \\
5=\text { International } \\
6=\text { No Response }\end{array}$ \\
\hline D4 & Place of Residence & Text & $\begin{array}{c}\text { Open Question } \\
\text { NR = No Response }\end{array}$ \\
\hline
\end{tabular}

Data relating to the perceptions of visitors to the Lake Claremont PGI space regarding the importance and performance of 22 attributes of quality PGI were gathered using the question shown in Figure 1.

\section{How important are the following features of Lake Claremont to you and how satisfied are you with their management?}

\begin{tabular}{|c|c|c|c|c|c|c|c|c|c|c|c|}
\hline $\begin{array}{l}\text { Item } \\
\text { For each feature listed below, please indicate: }\end{array}$ & \multicolumn{5}{|c|}{$\begin{array}{l}\text { Column A } \\
\text { Importance }\end{array}$} & \multicolumn{6}{|c|}{$\begin{array}{l}\text { Column B } \\
\text { Satisfaction }\end{array}$} \\
\hline $\begin{array}{l}\text { For each feature listed below, please indicate: } \\
\text { 1) The Importance of the feature by circling the } \\
\text { most relevant the number in Column A. } \\
\text { 2) Your Satisfaction with that feature by circling } \\
\text { the appropriate number in Column B. } \\
\text { If you have not experienced a listed feature during } \\
\text { today's visit, then please place an X under 'Unable } \\
\text { to Report' at far right of Column B (Satisfaction). }\end{array}$ & 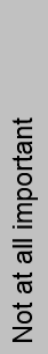 & 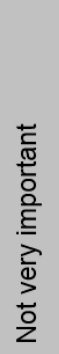 & 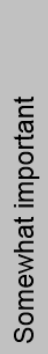 & 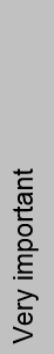 & 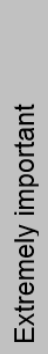 & 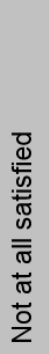 & 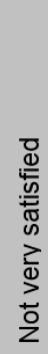 & 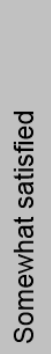 & 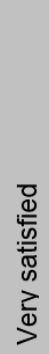 & 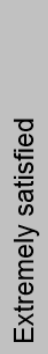 & 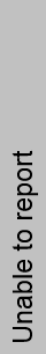 \\
\hline Availability of shade (trees or structures) & 1 & 2 & 3 & 4 & 5 & 1 & 2 & 3 & 4 & $v$ & \\
\hline $\begin{array}{l}\text { Bird watching infrastructure (observation } \\
\text { deck, rotunda) }\end{array}$ & 1 & 2 & 3 & 4 & 5 & 1 & 2 & 3 & 4 & 5 & \\
\hline Children's playground(s) & 1 & 2 & 3 & 4 & 5 & 1 & 2 & 3 & 4 & 5 & \\
\hline Directional signs within the park & 1 & 2 & 3 & 4 & 5 & 1 & 2 & 3 & 4 & 5 & \\
\hline Dog exercise area & 1 & 2 & 3 & 4 & 5 & 1 & 2 & 3 & 4 & 5 & \\
\hline Ease of access to and around the site & 1 & 2 & 3 & 4 & 5 & 1 & 2 & 3 & 4 & 5 & \\
\hline
\end{tabular}

Figure 1. An extract from the survey question used to gather data regarding visitor perceptions of the Importance of attributes of the Lake Claremont public green infrastructure (PGI) and urban nature (UN) spaces and the Performance of those attributes in meeting visitor expectations (measured as visitor satisfaction).

The 22 attributes of quality PGI spaces used to assess the perceptions of PGI users regarding the Lake Claremont PGI space are reported in Table 4, and the possible responses for the perceived importance and performance of those attributes are reported in Tables 5 and 6. 
Table 4. The metadata specification for identifiers of Importance and Performance ranking data.

\begin{tabular}{|c|c|c|c|}
\hline Attribute & $\begin{array}{c}\text { Importance } \\
\text { Ranking Identifier }\end{array}$ & $\begin{array}{c}\text { Performance } \\
\text { Ranking Identifier }\end{array}$ & $\begin{array}{l}\text { References Reporting } \\
\text { PGI Attribute }\end{array}$ \\
\hline 1. Availability of shade (trees or structures) & IA1 & PA1 & [19-21] \\
\hline 2. Bird watching infrastructure (observation deck, rotunda) & IA2 & PA2 & [22-25] \\
\hline 4. Directional signs within the park & IA4 & PA4 & {$[19,22,31-33]$} \\
\hline 5. Dog exercise area & IA5 & PA5 & {$[19,34]$} \\
\hline 6. Ease of access to and around the site & IA6 & PA6 & {$[25,30,35-38]$} \\
\hline $\begin{array}{l}\text { 9. High-quality infrastructure (paths, lights, toilets, barbeque } \\
\text { (BBQ), benches) }\end{array}$ & IA9 & PA9 & {$[31,33,42-48]$} \\
\hline 10. High-quality lake water body & IA10 & PA10 & {$[3,49-51]$} \\
\hline 11. High-quality nature spaces and areas & IA11 & PA11 & {$[23,26,30,43,46,52-54]$} \\
\hline 12. High-quality services (café, gym, golf club) & IA12 & PA12 & {$[24,31,33,42,44-48]$} \\
\hline 13. High-quality turf & IA13 & PA13 & {$[19,33,34]$} \\
\hline $\begin{array}{l}\text { 18. Other sporting installations (Aquatic Centre, } \\
\text { Cricket/Hockey Oval, and/or Tennis Club) }\end{array}$ & IA18 & PA18 & Site-Specific \\
\hline 19. Par 3 Golf Course & IA19 & PA19 & Site-Specific \\
\hline 20. Park exercise equipment & IA20 & PA20 & Site-Specific \\
\hline 21. Personal safety & IA21 & PA21 & {$[32,33,43]$} \\
\hline 22. Tree management & IA22 & PA22 & {$[20-22,30,42,45,55]$} \\
\hline
\end{tabular}

Table 5. The metadata specification for Importance of Attributes ranking data.

\begin{tabular}{ccc}
\hline Importance Ranking Identifier & Data Type & \multicolumn{1}{c}{ Data Values } \\
\hline & & $1=$ Not at all important \\
IA1 to IA22 & & $2=$ Not very important \\
& Categorical & $3=$ Somewhat important \\
& & $4=$ Very important \\
& & $5=$ Extremely important \\
\hline
\end{tabular}

Table 6. The metadata specification for Performance of Attributes ranking data.

\begin{tabular}{cll}
\hline Performance Ranking Identifier & Data Type & \multicolumn{1}{c}{ Data Values } \\
\hline & & $1=$ Not at all satisfied \\
& & $2=$ Not very satisfied \\
PA1 to PA22 & Categorical & $=$ Somewhat satisfied \\
& $4=$ Very satisfied \\
& $5=$ Extremely satisfied \\
& & $=$ Unable to report \\
\hline
\end{tabular}

\section{Methods}

\subsection{Study Site}

The visitor satisfaction data reported in this Data Descriptor were collected at the Lake Claremont PGI and UN space in Perth, Western Australia (31.9738 $\left.\mathrm{S}, 115.7771^{\circ} \mathrm{E}\right)$. Additional information regarding the location, land-use history, current condition, and utilization of the mixed-use Lake Claremont PGI and UN spaces are provided in Parker [10], Parker and Simpson [12], and Simpson and Newsome [3]. Location and surrounding land-use maps are provided in Simpson and Newsome [3] and Parker and Simpson [12], respectively. The following paragraph provides a short summary of the geomorphology and vegetation of the study site.

Lake Claremont is located on the Tamala Limestone zone of the Swan Coastal Plain at the boundary of the Quinadlaup Dune System and the older Spearwood Dune System [3,56]. Under the Koppen climate classification, the Southwest of Western Australia experiences a Mediterranean climate with hot dry summers and cooler wetter winters $[18,57,58]$. The traditional custodians of the 
land, the people of the Noongar nation, identify six seasons for this region [58,59]. Prior to European colonization, the indigenous vegetation of the region was a mix of Agonis and Tuart Woodlands and Banksia Woodlands [3,60-62]. As described by Simpson and Newsome [3], the site was heavily modified and degraded as a result of European colonization. Today, the vegetation present at the site is a mix of remnant and renatured indigenous vegetation in the $\mathrm{UN}$ spaces to the west and north of the lake, while the eastern and southern sides of the lake consist primarily of grassed areas with a mix of trees that are exotic, local native, and out-of-area 'native' species [3]. Lake Claremont is listed as a Conservation Category Wetland in the Government of Western Australia Geomorphic Wetlands: Swan Coastal Plain dataset $[3,63]$. The remnant and renatured indigenous vegetation of Lake Claremont and the surrounding PGI and UN spaces has a level of protection under the Bush Forever Site 220 and Environmentally Sensitive Area classifications of the Government of Western Australia and through the Government of Australia's classification of the remnant Banksia Woodland of the Swan Coastal Plain as an Endangered Ecological Community [3,64-66].

\subsection{Survey}

To inform the development of the survey questionnaire, relevant literature was consulted $[11,13]$ guided by Pickering and Byrne [67] and the PRISMA method of Moher et al. [68]. The sourced literature revealed a number of universally recognized PGI features, such as access paths, open turf areas, seating, infrastructure, and playgrounds. These universally recognized PGI features were assessed in terms of their presence at the Lake Claremont study site and suitability for inclusion in the IPA question of the survey. The questionnaire asked three tick-box categorical demographic questions (Tables 1-3) and one IPA question (Figure 1). The demographic question regarding a usual place of residence of the participant included an open-ended aspect that allowed participants to share the suburb, town, Australian state, and/or country that represented their usual place of residence. The IPA question assessed the perceptions of PGI users regarding the importance and performance of 22 attributes of quality PGI spaces (Tables 4-6) that were rated on a five-point Likert scale for importance and a six-point Likert scale, which incorporated an Unable to Report option, for performance.

A power analysis was undertaken prior to surveying to ensure that sufficient participant numbers would be achieved to allow for valid inferences to be drawn from the results [69]. It was determined that 259 participants were required to be $90 \%$ confident that detected differences between the performance of attributes were a valid effect at an $\alpha=0.05$ level of statistical significance assuming a correlation of $\rho=0.2$ between the Importance and Performance rankings of survey participants. The responses from 393 analyzable questionnaires are shared via the dataset connected to this Data Descriptor.

Participants were recruited through a convenience intercept approach to surveying PGI users. Several survey events were scheduled at differing times of the day and across all days of the week during December 2016 and January 2017 to limit the potential for response bias and cognitive bias (i.e., an elevated response of participants during the festive season or weekends in comparison to day-to-day life).

Once completed, participants immediately returned their anonymous, self-reported, pen-and-paper-based questionnaires to the researchers who secured the questionnaire for later transcription of the data. After each field survey event, de-identified responses of participants were recorded in an Excel workbook for analysis and storage.

\subsection{Limitations and Learnings}

The survey reported in this Data Descriptor and the research article of Parker and Simpson [12] was the first time that either author had utilized the IPA technique. For that reason, the authors adapted the questionnaire developed and tested by others to conduct the IPA study reported in Newsome et al. [14] for their PGI research. Unfortunately, only after the data collection phase of the PGI survey was completed did it become apparent that there was a non-fatal flaw in the design of the 
IPA question from the survey of Newsome et al. [14] that had consequently been carried over to the PGI survey.

Two important, but rarely considered, assumptions that underpin the Likert scale are that the ordinal categories have the same span or intensity and that the mid-point of the scale is a neutral inflection point between the negative response categories and positive response categories [70-72]. Those assumptions are generally met by constructing a Likert scale with an equal number of matched positive and negative categories. The assumption of a neutral mid-point is met either by providing an explicitly stated neutral mid-point on a Likert scale with an odd number of categories, or implicitly through the use of a forced-choice Likert scale that has an even number of categories [70,73]. As its name suggests, a forced-choice Likert scale requires survey participants to express either a positive or a negative view either side of the unstated neutral mid-point. The combination of these two assumptions provides the opportunity for a linear relationship to exist between the importance and performance of the assessed attributes that is implicit in a Martilla and James [74] IPA Matrix [10,16,75].

It will now be self-evident that the IPA question presented in Figure 1 utilities a forced-choice Likert scale with three positive response categories and just two negative response categories. While not fatal for the IPAs presented in Newsome et al. [14] and Parker and Simpson [12], it does mean that the negative ordinal categories of the dataset shared in this Data Descriptor span a slightly wider range than the span for the positive categories, and the mid-point of the scale has a value of 2.5 rather than the value of 3 as would normally apply for a 5-point Likert scale.

Supplementary Materials: Lake Claremont IPA Dataset.csv is available online at http:/ / www.mdpi.com/23065729/3/4/69/s1.

Author Contributions: G.S. and J.P. made equal contributions to this paper and as such are co-first authors.

Funding: This research received no external funding.

Acknowledgments: We thank our colleague David Newsome for his guidance of J.P.'s research and comments on the associated thesis. We thank Dianne Parker for her efforts in transcribing the anonymous survey data from the self-report questionnaires to an Excel spreadsheet. This research was undertaken under Murdoch University Human Ethics Committee Approval 2016/213.

Conflicts of Interest: The authors declare no conflict of interest.

\section{References}

1. Beatley, T. Biophilic Cities: Integrating Nature into Urban Design and Planning; Island Press: Washington, DC, USA, 2011; ISBN 978-1-59-726715-1.

2. Kopecká, M.; Szatmári, D.; Rosina, K. Analysis of urban green spaces based on Sentinel-2A: Case studies from Slovakia. Land 2017, 6, 25. [CrossRef]

3. Simpson, G.; Newsome, D. Environmental history of an urban wetland: From degraded colonial resource to nature conservation area. Geo Geogr. Environ. 2017, 4, e00030. [CrossRef]

4. Wilson, E.O. Biophilia; Harvard University Press: Cambridge, MA, USA, 1984; ISBN 978-0-67-407442-2.

5. Miller, J.R. Biodiversity conservation and the extinction of experience. Trends Ecol. Evol. 2005, 20, 430-434. [CrossRef] [PubMed]

6. Neuman, M. The compact city fallacy. J. Plan. Educ. Res. 2005, 25, 11-26. [CrossRef]

7. Jones, C.; Newsome, D. Perth (Australia) as one of the world's most liveable cities: A perspective on society, sustainability and environment. Int. J. Tour. Cities 2015, 1, 18-35. [CrossRef]

8. Newton, P.W. Liveable and sustainable? Socio-technical challenged for the twenty-first century cities. J. Urban Technol. 2012, 19, 81-102. [CrossRef]

9. Okulicz-Kozaryn, A. City life: Rankings (liveability) versus perceptions (satisfaction). Soc. Indic. Res. 2011, 110, 433-451. [CrossRef]

10. Parker, J.A. Survey of Park User Perception in the Context of Green Space and City Liveability: Lake Claremont, Western Australia. Master's Thesis, Murdoch University, Perth, Australia, 2017. Available online: http:/ / researchrepository.murdoch.edu.au/id/eprint/40856/ (accessed on 8 October 2018). 
11. Parker, J.; Simpson, G.D. Public Green Infrastructure Contributes to City Liveability: A Systematic Quantitative Review. Land 2018, 7. in press.

12. Parker, J.; Simpson, G. Visitor Satisfaction with a Public Green Infrastructure and Urban Nature Space in Perth, Western Australia. Land 2018, 7. in press.

13. Simpson, G.D.; Parker, J. Data on Peer Reviewed Papers about Green Infrastructure, Urban Nature, and City Liveability. Data 2018, 3, 51. [CrossRef]

14. Newsome, D.; Rodger, K.; Pearce, J.; Chan, K.L.J. Visitor satisfaction with a key wildlife tourism destination within the context of a damaged landscape. Curr. Issues Tour. 2017. [CrossRef]

15. Soldić Frleta, D. Island destinations' tourism offer-tourists' vs. residents' attitudes. Tour. Hosp. Manag. 2014, 20,1-14. Available online: https:/ / hrcak.srce.hr/123774 (accessed on 15 December 2018).

16. Taplin, R.H. Competitive importance-performance analysis of an Australian wildlife park. Tour. Manag. 2012, 33, 29-37. [CrossRef]

17. Patroni, J.; Day, A.; Lee, D.; Chan, J.K.L.; Kerr, D.; Newsome, D.; Simpson, G.D. Looking for evidence that place of residence influenced visitor attitudes to feeding wild dolphins. Tour. Hosp. Manag. 2018, 24, 87-105. [CrossRef]

18. Simpson, G.; Newsome, D.; Day, A. Data from a survey to determine visitor attitudes and knowledge about the provisioning of wild dolphins at a marine tourism destination. Data Brief 2016, 9, 940-945. [CrossRef] [PubMed]

19. Crawford, D.; Timperio, A.; Giles-Corti, B.; Ball, K.; Hume, C.; Roberts, R.; Andrianopoulos, N.; Salmon, J. Do features of public open spaces vary according to neighbourhood socio-economic status? Health Place 2008, 14, 889-893. [CrossRef] [PubMed]

20. Norton, B.A.; Coutts, A.M.; Livesley, S.J.; Harris, R.J.; Hunter, A.M.; Williams, N.S. Planning for cooler cities: A framework to prioritise green infrastructure to mitigate high temperatures in urban landscapes. Landsc. Urban Plan. 2015, 134, 127-138. [CrossRef]

21. Shackleton, S.; Chinyimba, A.; Hebinck, P.; Shackleton, C.; Kaoma, H. Multiple benefits and values of trees in urban landscapes in two towns in northern South Africa. Landsc. Urban Plan. 2015, 136, 76-86. [CrossRef]

22. Barth, B.J.; FitzGibbon, S.I.; Wilson, R.S. New urban developments that retain more remnant trees have greater bird diversity. Landsc. Urban Plan. 2015, 136, 122-129. [CrossRef]

23. Dallimer, M.; Irvine, K.N.; Skinner, A.M.; Davies, Z.G.; Rouquette, J.R.; Maltby, L.L.; Warren, P.H.; Armsworth, P.R.; Gaston, K.J. Biodiversity and the feel-good factor: Understanding associations between self-reported human well-being and species richness. BioScience 2012, 62, 47-55. [CrossRef]

24. Irvine, K.N.; Devine-Wright, P.; Payne, S.R.; Fuller, R.A.; Painter, B.; Gaston, K.J. Green space, soundscape and urban sustainability: An interdisciplinary, empirical study. Local Environ. 2009, 14, 155-172. [CrossRef]

25. Sushinsky, J.R.; Rhodes, J.R.; Possingham, H.P.; Gill, T.K.; Fuller, R.A. How should we grow cities to minimize their biodiversity impacts? Glob. Chang. Biol. 2012, 19, 401-410. [CrossRef] [PubMed]

26. Bratman, G.N.; Hamilton, P.; Daily, G.C. The impacts of nature experience on human cognitive function and mental health. N. Y. Acad. Sci. 2012, 1249, 118-136. [CrossRef] [PubMed]

27. Hausmann, A.; Slotow, R.O.B.; Burns, J.K.; Di Minin, E. The ecosystem service of sense of place: Benefits for human well-being and biodiversity conservation. Environ. Conserv. 2016, 43, 117-127. [CrossRef]

28. Raquel, C.D.S.M.; Montalto, F.A.; Palmer, M.I. Potential climate change impacts on green infrastructure vegetation. Urban For. Urban Green. 2016, 20, 128-139. [CrossRef]

29. Salata, K.; Yiannakou, A. Green Infrastructure and climate change adaptation. TeMA J. Land Use Mobil. Environ. 2016, 9, 7-24.

30. Thompson, C.W. Urban open space in the 21st century. Landsc. Urban Plan. 2002, 60, 59-72. [CrossRef]

31. Cattell, V.; Dines, N.; Gesler, W.; Curtis, S. Mingling, observing, and lingering: Everyday public spaces and their implications for well-being and social relations. Health Place 2008, 14, 544-561. [CrossRef]

32. Francis, J.; Giles-Corti, B.; Wood, L.; Knuiman, M. Creating sense of community: The role of public space. J. Environ. Psychol. 2012, 32, 401-409. [CrossRef]

33. Giles-Corti, B.; Broomhall, M.H.; Knuiman, M.; Collins, C.; Douglas, K.; Ng, K.; Lange, A.; Donovan, R.J. Increasing walking: How important is distance to attractiveness, and size of public open space? Am. J. Prev. Med. 2005, 28, 169-176. [CrossRef]

34. Sugiyama, T.; Gunn, L.D.; Christian, H.; Francis, J.; Foster, S.; Hooper, P.; Owen, N.; Giles-Corti, B. Quality of public open spaces and recreational walking. Am. J. Public Health 2015, 105, 2490-2495. [CrossRef] [PubMed] 
35. Appiah-Opoku, S. Using protected areas as a tool for biodiversity conservation and ecotourism: A case study of Kakum National Park in Ghana. Soc. Nat. Resour. 2011, 24, 500-510. [CrossRef]

36. Hillsdon, M.; Panter, J.; Foster, C.; Jones, A. The relationship between access and quality of urban green space with population physical activity. Public Health 2006, 120, 1127-1132. [CrossRef] [PubMed]

37. Keniger, L.E.; Gaston, K.J.; Irvine, K.N.; Fuller, R.A. What are the benefits of interacting with nature? Int. J. Environ. Res. Public Health 2013, 10, 913-935. [CrossRef] [PubMed]

38. Van Herzele, A.; Wiedemann, T. A monitoring tool for the provision of accessible and attractive urban green spaces. Landsc. Urban Plan. 2003, 63, 109-126. [CrossRef]

39. Balding, M.; Williams, K.J. Plant blindness and the implications for plant conservation. Conserv. Biol. 2016, 30, 1192-1199. [CrossRef]

40. Chen, B.; Adimo, O.A.; Bao, Z. Assessment of aesthetic quality and multiple functions of urban green space from the users' perspective: The case of Hangzhou Flower Garden, China. Landsc. Urban Plan. 2009, 93, 76-82. [CrossRef]

41. Green, T.L.; Kronenberg, J.; Andersson, E.; Elmqvist, T.; Gómez-Baggethun, E. Insurance value of green infrastructure in and around cities. Ecosystems 2016, 19, 1051-1063. [CrossRef]

42. Grose, M.J. Changing relationships in public open space and private open space in suburbs in south-western Australia. Landsc. Urban Plan. 2009, 92, 53-63. [CrossRef]

43. Ikin, K.; Le Roux, D.S.; Rayner, L.; Villaseñor, N.R.; Eyles, K.; Gibbons, P.; Manning, A.D.; Lindenmayer, D.B. Key lessons for achieving biodiversity-sensitive cities and towns. Ecol. Manag. Restor. 2015, 16, $206-214$. [CrossRef]

44. Antognelli, S.; Vizzari, M. Landscape liveability spatial assessment integrating ecosystem and urban services with their perceived importance by stakeholders. Ecol. Indic. 2017, 72, 703-725. [CrossRef]

45. Shanahan, D.F.; Lin, B.B.; Bush, R.; Gaston, K.J.; Dean, J.H.; Barber, E.; Fuller, R.A. Toward improved public health outcomes from urban nature. Am. J. Public Health 2015, 105, 470-477. [CrossRef] [PubMed]

46. Soga, M.; Yamaura, Y.; Aikoh, T.; Shoji, Y.; Kubo, T.; Gaston, K.J. Reducing the extinction of experience: Association between urban form and recreational use of public greenspace. Landsc. Urban Plan. 2015, 143, 69-75. [CrossRef]

47. Taylor, B.T.; Fernando, P.; Bauman, A.E.; Williamson, A.; Craig, J.C.; Redman, S. Measuring the quality of public open space using Google Earth. Am. J. Prev. Med. 2011, 40, 105-112. [CrossRef] [PubMed]

48. Villanueva, K.; Badland, H.; Hooper, P.; Koohsari, M.J.; Mavoa, S.; Davern, M.; Roberts, R.; Goldfeld, S.; Giles-Corti, B. Developing indicators of public open space to promote health and wellbeing in communities. Appl. Geogr. 2015, 57, 112-119. [CrossRef]

49. Dale, P.E.R.; Connelly, R. Wetlands and human health: An overview. Wetl. Ecol. Manag. 2012, $20,165-171$. [CrossRef]

50. Do, Y.; Kim, S.B.; Kim, J.Y.; Joo, G.J. Wetland-based tourism in South Korea: Who, When, and Why. Wetl. Ecol. Manag. 2015, 23, 779-787. [CrossRef]

51. Revell, G.; Anda, M. Sustainable urban biophilia: The case of greenskins for urban density. Sustainability 2014, 6, 5423-5438. [CrossRef]

52. Andersson, E.; Barthel, S.; Borgström, S.; Colding, J.; Elmqvist, T.; Folke, C.; Gren, Å. Reconnecting Cities to the Biosphere: Stewardship of Green Infrastructure and Urban Ecosystem Services. Ambio 2014, 43, 445-453. [CrossRef]

53. Battisti, C. Experiential key species for the nature-disconnected generation. Anim. Conserv. 2016, 19, 485-487. [CrossRef]

54. Van den Berg, A.E.; Hartig, T.; Staats, H. Preference for nature in urbanized societies: Stress, restoration, and the pursuit of sustainability. J. Soc. Issues 2007, 63, 79-96. [CrossRef]

55. Hartig, T.; Evans, G.W.; Jamner, L.D.; Davis, D.S.; Gärling, T. Tracking restoration in natural and urban field settings. J. Environ. Psychol. 2003, 23, 109-123. [CrossRef]

56. Tapsell, P.; Newsome, D.; Bastian, L. Origin of yellow sand from Tamala limestone on the Swan Coastal Plain, Western Australia. Aust. J. Earth Sci. 2003, 50, 331-342. [CrossRef]

57. Met Office. Helping You Understand Weather and Climate; Met Office, Government of the UK: Exeter, UK, 2012; pp. 2-3. 
58. Simpson, G.D. Cracking the Niche: An Investigation into the Impact of Climatic Variables on Germination of the Rare Shrub Verticordia staminosa Subspecies staminosa (Myrtaceae). Honours Thesis, Murdoch University, Perth, Australia, 2011. Available online: http://researchrepository.murdoch.edu.au/id/eprint/8485/ (accessed on 25 October 2018).

59. South West Aboriginal Land \& Sea Council. Kaartdijin in Noongar-Noongar Knowledge: Sharing Noongar Culture. Available online: https:/ / www.noongarculture.org.au/ (accessed on 27 October 2018).

60. Beard, J.S. Definition and locations of the Banksia woodlands. J. R. Soc. West. Aust. 1989, 71, 85-86.

61. Fowler, W. Soil Seed Bank Dynamics in Transferred Topsoil: Evaluating Restoration Potentials. Honours Thesis, Murdoch University, Perth, Australia, 2012. Available online: http:/ / researchrepository.murdoch. edu.au/id/eprint/13389/ (accessed on 25 October 2018).

62. Ritchie, A.; Sinclair, E.; Stevens, J.; Commander, L.; Davis, R.; Fowler, W. EcoCheck: Perth's Banksia Woodlands Are in the Path of the Sprawling City. The Conversation 2016. Available online: https:// theconversation.com/ecocheck-perths-banksia-woodlands-are-in-the-path-of-the-sprawling-city-59911 (accessed on 27 October 2018).

63. Government of Western Australia. Geomorphic Wetlands, Swan Coastal Plain (DBCA-019). Available online: https: / catalogue.data.wa.gov.au/dataset/geomorphic-wetlands-swan-coastal-plain (accessed on 22 November 2018).

64. Government of Western Australia: Department of Water Environmental Regulation. Environmentally Sensitive Areas. Available online: https://www.der.wa.gov.au/your-environment/environmentallysensitive-areas (accessed on 22 November 2018).

65. Government of Western Australia: Department of Planning, Lands, and Heritage. Bush Forever: Volume 2: Directory of Bush Forever. Available online: https://www.planning.wa.gov.au/publications/5911.aspx (accessed on 22 November 2018).

66. Australian Government. Species Profile and Threats Database: Banksia Woodlands of the Swan Coastal Plain Ecological Community. Available online: http:/ /www.environment.gov.au/cgi-bin/sprat/public/ publicshowcommunity.pl?id=131\&status=Endangered (accessed on 22 November 2018).

67. Pickering, C.M.; Byrne, J. The benefits of publishing systematic quantitative literature reviews for PhD candidates and other early career researchers. High. Educ. Res. Dev. 2013, 33, 534-548. [CrossRef]

68. Moher, D.; Liberati, A.; Tetzlaff, J.; Altman, D.G. Preferred reporting items for systematic reviews and meta-analyses: The PRISMA statement. Ann. Intern. Med. 2009, 151, 264-269. [CrossRef] [PubMed]

69. Francis, G.; Garing, A. Foundations of Statistics; Pearson Australia: Sydney, Australia, 2013; ISBN 978-1-48-861343-2.

70. Albaum, G. The Likert scale revisited. Mark. Res. Soc. J. 1997, 39, 1-21. [CrossRef]

71. Babbie, E.R. The Practice of Social Research, 6th ed.; Wadsworth Publishing Company: Belmont, CA, USA, 1992; pp. 180-181. ISBN 0-534-15576-6.

72. Sarantakos, S. Social Research, 2nd ed.; Macmillan Education Australia Pty. Ltd.: South Yarra, Australia, 1998; pp. 89-90. ISBN 0-7329-4577-1.

73. Jennings, G. Tourism Research; John Wiley \& Sons: Milton, Australia, 2001; ISBN 978-0471342557.

74. Martilla, J.A.; James, J.C. Importance-Performance Analysis. J. Mark. 1977, 41, 77-79. [CrossRef]

75. Oh, H. Revisiting importance-performance analysis. Tour. Manag. 2001, 22, 617-627. [CrossRef]

(C) 2018 by the authors. Licensee MDPI, Basel, Switzerland. This article is an open access article distributed under the terms and conditions of the Creative Commons Attribution (CC BY) license (http:/ / creativecommons.org/licenses/by/4.0/). 